\title{
Customer's' Perception of the Use of Arabic Terminology in Sharia Banking Products
}

\author{
Muhammad Yafiz, Isnaini Harahap, Marliyah, and Chuzaimah Batubara \\ Universitas Islam Negeri Sumatera Utara (UIN SU), Medan, Indonesia
}

\section{Abstract}

Sharia banking as an Islamic financial institution was founded as the response to conventional banking. The response was realized with the spirit of providing different services and performance (sharia compliance) with those offered by conventional banks. One of these differences can be seen from the use of Arabic (figh) terms in various Islamic banking products. However, as an Islamic financial institution established in the midst of heterogeneous communities, the use of these terms could be problematic. This on-going research aims to investigate the perception of sharia banking customers in Medan on the use of Arabic (fiqh) terminology in its products. A qualitative approach using questionnaire and interview as the instruments of data

Corresponding Author: Muhammad Yafiz muhammadyafiz@uinsu.ac.id

Received: 1 July 2019

Accepted: 18 July 2019

Published: 31 July 2019

Publishing services provided by Knowledge E

(c) Muhammad Yafiz et al. This article is distributed under the terms of the

Attribution License, which permits unrestricted use and redistribution provided that the original author and source are credited.

Selection and Peer-review under the responsibility of the AICLL 2019 Conference Committee.

\section{S OPEN ACCESS} collection is applied in this study. The interim results show that most of the customers do not oppose the use of Arabic terms in Islamic banking products, however they also show a lack of understanding of the terms used. Based on these findings, this study offers two possible recommendation; first, it is necessary to socialize and educate the customers of the Arabic terms in the Islamic banking products. Two, if the customers find them difficult to understand, it is suggested that the terms are replaced by more familiar ones in the banking world while maintaining its sharia substance.

Keywords: Arabic terminology, Islamic banking, customer, perception, sharia.

\section{Introduction}

The presence of Islamic banks in Indonesia is an answer to the wishes of people who want to follow the sharia banking. Islamic banking in Indonesia has been existed for two decades since the establishment of PT. Bank Muamalat Indonesia (BMI) in 1991. Its development is quite significant as evidenced by the increasing number of conventional banks that either establish or turn into sharia banking. With the increasing of sharia financial institutions, the Islamic financial products offered become varied and are gradually developing. From the law perspectives, the method used in applying the contracts to Islamic bank in Indonesia is accommodative, meaning that they represent conventional banks in all of their operations. This is due to the development strategy which is more focused on achieving the market size (Darsono \& Sakti, 2017). 
Most Islamic banking products in Indonesia are introduced as alternatives to conventional banking products. Therefore, Islamic banks need to create new products in order to be more competitive. Some experts in Muslim economists point out that one of the obstacles to the development of Islamic banks is the lack understanding within the community about the operations and products of Islamic banks (Hermawan Adinugraha, 2017). There are some factors causing this condition that include the fact that Islamic banks have not used maximum effort in socializing their products. Another factor is related to linguistic aspect since the terms used to label the products are mostly in Arabic. It is important to highlight that the customers of Islamic banks are Muslims and non-Muslims. For this reason, there is possibility that the non-Muslim customers are not familiar and understand the products as "Islamic banking system's derivation from the sharia perspectives and it is consistent with Shariah guidelines which are based on the commandments of Quran and Sunnah" (Musse, 2015).

Regarding the issues related to customers' understanding of sharia banking products, this study was aimed to investigate the perception of Islamic bank customers in Medan towards the use of Arabic terminology for the banking products. The findings of this study may inform Islamic banking institutions, especially those in Medan to which level their customers understand their products. Furthermore, they can use the information design strategic plans focusing on marketing policies for their customers.

\section{Literature Review}

\subsection{Perception}

Perception is the process of organizing, interpreting the stimulus received by individual so that it becomes something meaningful as integrated activity in the individuals (Walgito, 2013). William James stated that perception is formed on the basis of data obtained from memory processing which is reprocessed based on experience (Rukminto Adi, 1994). Rokeach mentions that there are congnitive and conative components in perception, and they are considered as predisposing attitude to respond and to behave (Walgito, 2003).

Fithriani (2018a) stated that perception is "sometimes distorted by a number of aspects residing in the perceiver, in the object or target being perceived, or in the context of the situation in which the perception is made" (p. 2). One important aspect residing in the perceiver is attention, which is a process of selecting inputs that will be processed in relation to experience. Things that affect one's attention can be seen from internal 
and external factors. The internal factors are motives and needs, preparatory set (one's readiness to respond a particular sensory input), and interest. Meanwhile, the external factors are intensity and size, for example; the harder the sound the better it attracts attention; contrast and new things, repetition, and movement.

Perception has a crucial role on the success of an idea offered (Fithriani, 2019). In this case, the success of Islamic banking products is closely related to customers' perceptions of these products, which can be influenced by various factors including their understanding of the terminology used. Thus, it is important for Islamic banking institutions to take into consideration customers' perception of the use of Arabic terminology in their products and services.

\subsection{Arabic terms}

So far, the efforts of developing Islamic banking products have been emphasized more on the form of services and transactions. Innovations for Islamic banking products from time to time continue to be developed and improved. As an effort to distinguish the characteristics between Islamic banks and conventional banks, the Islamic banks use the symbols of Islam and Arabic language. Therefore, it is natural if Islamic banks are stigmatized in society as exclusive bank. Islamic banks seem to be only understood by Muslim communities. The symbol of exclusivity is also attached to the names of Islamic banking products that always prioritize the Arabic terms, regardless of the effectiveness and efficiency of the use of the terms among the plural society (Ghoni, Suripto, \& Salam, 2016).

Islamic banking uses the Fiqh rules for the product innovations, meaning that the changes in law (muamalah) along with the changes in times, places, and circumstances. Based on the Fiqh rule, muamalah law is dynamic and elastic. The fulfillment of people's preferences for the banking products that are tailored to the needs of the times, places, and conditions should also be guided by the MUI fatwa stipulated by the National Sharia Council of Indonesian Ulema Council (Werdi Apriyanti, 2018).

In general, the community does not understand well about the Arabic terms used in the scheme of Islamic banking products. The community is more accustomed to understand Indonesian and English terms which are commonly used in conventional bank products (Ghoni et al., 2016), especially the specific terms in English since English has been widely spoken by people of different mother tongues (lingua franca) (Fithriani, 2018b). 


\subsection{Islamic banking products}

Islamic banks are different from conventional ones. In carrying out their operations, Islamic banks follow the rules that have been set by the sharia, such as; being free from debt, gharar and usury or what is commonly referred as maghrib. Islamic banks have dual roles. Besides acting as a profit-seeking institutions, they also act as social institutions. As a profit-making institution, Islamic banks conduct business activities that bring profits through the creation of products based on certain contracts.

Like the conventional banks, Islamic banks conduct business activities, either by raining funds or channeling them bank to the community. For these activities, many Islamic banks use Arabic terms that are still unfamiliar to the public. For example, in financing with a sharia banking profit sharing system, Mudharabah is used as the contract. Mudharabah is a partnership agreement in which the capital or assets of one party and the power or managerial of the other party by sharing the profit (Abdul Sattar Ali Hasan, 2011). Islam implies a Mudharabah to provide convenience because some people have assets, but are unable to manage them while some do not have assets but have the ability to manage and develop them (Marliyah, 2016). Besides Mudharabah, Musyarakah is also applied in which both parties contribute to each other's capital and manage the business together. In the financing of selling and buying, the terms Murabahah, salam, and istisna are common. Murabahah is the selling and buying contract where the capital and profits are transparent to both parties (Rusyd, n.d.). Meanwhile, salam and istisna' are the selling and buying with orders, the difference is just the way of payment (Sabiq, 1983). Salam is paid in advance at once while istisna' can be paid up front, in the middle, or at the end. In addition, Islamic banking also uses the ljarah and ljarah muntahiya bit tamlik (IMBT). ljarah is a leasing contract while IMBT is a leasing agreement which ends with the transfer of ownership of the good leased to the tenants (Al-Jaziriy, 1990) The majority of Islamic banking products use Arabic terms in the products they issue.

\section{Research Method}

This study is categorized as a field research with a mixed, quantitative-qualitative approach. The primary data of the study were obtained through questionnaires and in-depth interviews. The questionnaires were given to customers of Islamic banks as many as 60 respondents who were randomly selected. Then the interviews with 
the selected respondents were conducted to find out their perceptions of the Islamic banking products in Arabic terms.

The data were analyzed by using the technique proposed by Miles and Huberman, and it consists of data reduction, data presentation, data interpretation, and conclusion. To strengthen the validity of findings, the Lincoln and Guba standards were used that consist of credibility, transferability, dependency, and assertiveness.

\section{Result and Discussion}

Medan is the third largest city in Indonesia after Jakarta and Surabaya. Medan is a multiethnic city where the population consists of diverse communities with different cultural religious backgrounds. As one of the national economic centers, Medan has great potential for the development of Islamic banking industry. Therefore, market-based information is needed as a consideration in determining the right strategy for developing the Islamic banking system and tailored to the needs of the community.

\subsection{The characteristics of respondents}

TABLE 1: The characteristics of respondents.

\begin{tabular}{l|c|c|}
\hline Category & $\begin{array}{c}\text { The number of } \\
\text { respondents }\end{array}$ & Percentage \\
\hline Sex & 25 & \\
\hline Male & 35 & $42 \%$ \\
\hline Female & & $58 \%$ \\
\hline Profession & 12 & $20 \%$ \\
\hline Teachers/Lecturers & 20 & $33 \%$ \\
\hline University Students & 10 & $17 \%$ \\
\hline Employees & 12 & $20 \%$ \\
\hline Entrepreneurs & 6 & $10 \%$ \\
\hline Others & & \\
\hline Age & 21 & $35 \%$ \\
\hline$<25$ years old (yo) & 6 & $10 \%$ \\
\hline $26-30$ yo & 28 & $47 \%$ \\
\hline 31 - 35 yo & 3 & $5 \%$ \\
\hline $36-40$ yo & 2 & $3 \%$ \\
\hline$>41$ yo & & \\
\hline Source: 2019 Data & &
\end{tabular}


The profile of respondents can be seen in table 1 above. Based on the data in the table, it can be seen that the majority of respondents are female, that is equal to $58 \%$ while male respondents are $42 \%$. The job category is dominated by university students by $33 \%$, followed by teachers/lecturers and entrepreneurs by $20 \%$, employees $17 \%$, and others by $10 \%$. Based on the age category, the highest respondents are at the age of 31-35 years which is equal to $47 \%$, then under 25 years at 35\% and then $26-30$ years at $10 \%$ and $36-40$ years at $5 \%$. The lowest age category is above 41 years, which is only $2 \%$.

\subsection{The customer's perception of using the arabic terms in Sharia banks}

Before discussing customer's perceptions about the use of Arabic terms in Islamic banking products, the respondents were asked in advance about their knowledge of Islamic banks in general. Based on the results of the questionnaires distributed, the following data were obtained:

TABLE 2: The General Knowledge about Islamic Banking.

\begin{tabular}{|c|c|c|}
\hline Category & $\begin{array}{l}\text { The Number of } \\
\text { Respondents }\end{array}$ & Percentage \\
\hline \multicolumn{3}{|c|}{ Awareness about existence of Sharia Banks } \\
\hline Aware & 60 & $100 \%$ \\
\hline Unaware & 0 & $0 \%$ \\
\hline \multicolumn{3}{|c|}{ The Differences between Sharia Banking and Islamic Banking } \\
\hline Aware & 45 & $75 \%$ \\
\hline Doubtful & 9 & $15 \%$ \\
\hline Unaware & 6 & $10 \%$ \\
\hline \multicolumn{3}{|c|}{ The source of information related to Sharia Banking } \\
\hline Socialization & 33 & $55 \%$ \\
\hline Friends/Family & 6 & $10 \%$ \\
\hline Internet & 18 & $30 \%$ \\
\hline Social Media & 3 & $5 \%$ \\
\hline \multicolumn{3}{|c|}{ The distance between Islamic banks to the respondent's residence } \\
\hline$<5 \mathrm{~km}$ & 6 & $10 \%$ \\
\hline $6-10$ km & 12 & $20 \%$ \\
\hline$>10 \mathrm{~km}$ & 42 & $70 \%$ \\
\hline Source: 2019 Da & & \\
\hline
\end{tabular}

In the table above, it can be seen that all respondents are aware about the presence of Islamic banks and conventional banks. However, when asked about the differences 
about Islamic banks with conventional banks, the majority of respondents aware (75\%), doubtful (15\%), and unaware (10\%) or 6 respondents.

Regarding to the source of information to find out about Islamic banking, the majority of respondents answered that got the information from socializations given by the bank sector, namely; $33 \%$, followed by $30 \%$ internet surfing, $10 \%$ information from friends or family, and the finally from the mass media $5 \%$ or 3 respondents.

The existence of sharia banking offices should be taken into account for the ease of public access to the Islamic banks. Based on the results of the questionnaire, the distance between the location of the Islamic bank and the respondents' residence was above $10 \mathrm{~km}$ (70\%) while the 12 respondents answered between $6-10 \mathrm{~km}$, and $10 \%$ or 6 respondents answered less than $5 \mathrm{~km}$.

The socialization of Islamic banks to the society can also be seen from the contracts used in Islamic banks as one of the differentiators between Islamic banks and conventional banks. Based on the results of the questionnaires about the awareness of contracts in Islamic banks that were distributed to the respondents, the following results were obtained:

TABLE 3: The awareness of contracts in Islamic banks.

\begin{tabular}{|l|l|c|c|c|} 
No & Criteria & \multicolumn{3}{c|}{ The Number of Respondents } \\
\hline 1 & Awareness of wadiah & Aware & Doubtful & Unaware \\
\hline 2 & Awareness of Mudharabah & 21 & 15 & 24 \\
\hline 3 & Awareness of Musyarakah & 27 & 12 & 21 \\
\hline 4 & Awareness of Murabahah & 24 & 9 & 27 \\
\hline 5 & Awareness of salam & 30 & 18 & 12 \\
\hline 6 & Awareness of istisna' & 15 & 15 & 30 \\
\hline 7 & Awareness of ljarah & 9 & 3 & 48 \\
\hline 8 & Awareness ljarah muntahiya bit tamlik & 18 & 12 & 30 \\
\hline Source: 2019 Data & 12 & 3 & 45 \\
\hline
\end{tabular}

Based on the data in tables 3 and 4 above, it can be seen that wadiah is commonly used to collect funds from the public, and the respondents who are aware of this are 21 respondents or $35 \%$, who doubt about this are 15 respondents or $25 \%$ while those who do not know are 24 people or $40 \%$. There were 27 people or $45 \%$ of respondents who know about Mudharabah followed by respondents who do not know as many as $35 \%$ or 21 people while those who are in doubt are $20 \%$ or 12 people. Musyarakah contracts were understood by 24 people or $40 \%$, those who doubt about it are 9 people or $15 \%$, and those who do not know about this as many as 27 people or $45 \%$. 
TABLE 4: The Awareness of Contracts in Sharia Banking (in percentage).

\begin{tabular}{l|l|c|c|c|} 
No & Criteria & \multicolumn{3}{|c|}{ The percentage of respondents } \\
\hline 1 & Aware & Doubtful & Unaware \\
\hline 2 & Awareness of wadiah & 35 & 25 & 40 \\
\hline 3 & Awareness of Mudharabah & 45 & 20 & 35 \\
\hline 4 & Awareness of Murabahah & 40 & 15 & 45 \\
\hline 5 & Awareness of salam & 50 & 30 & 20 \\
\hline 6 & Awareness of istisna' & 25 & 25 & 50 \\
\hline 7 & Awareness of ljarah & 15 & 5 & 80 \\
\hline 8 & Awareness of ljarah muntahiya bit tamlik & 30 & 20 & 50 \\
\hline
\end{tabular}

Murabahah is a contract that is mostly used by Islamic banking. Regarding about this, the respondents who know about murabahah are as many as $50 \%$ or 30 people, who are in doubt are $30 \%$ or 18 people, and who do not know about this are as many as 12 people or $20 \%$. Regarding about Salam, the majority of respondents who do not know about this are as many as 30 people or 50\%, those who know and are in doubt are 15 people or $25 \%$ respectively. Regarding about Istisna', the majority of respondents who do not know about this are $80 \%$ followed by respondents who know about it as many as $15 \%$ and those who are in doubt are $5 \%$.

ljarah is a leasing contract commonly used by Islamic banking in meeting customer needs in the form of buildings or equipment. For this contract, as many as 18 people or $30 \%$ of respondents know about the contract while those who do not know are as many as $50 \%$ or 30 people and those who are in doubt are as many as $20 \%$ or 12 people.

The ljarah Muntahiya bit Tamlik contract is a lease contract which ends with the ownership of the goods leased after the lease term expires. Related to this contract, as many as $20 \%$ of respondents or 12 people understand about the contract while those who are in doubt are 3 or $5 \%$, and the majority of respondents who do not know about it are 45 people or $75 \%$.

Based on the results of the questionnaire above, it can be seen that in general the majority of the public does not know in detail about the contracts used in Islamic banking products. This is because the contract uses Arabic terms that are rarely heard and have not been heard by them. To find out more about the public response regarding the terms of Arabic used in Islamic banking contract, interviews were held with several respondents. From the interviews contacted, it is understood that they were rather difficult to understand the contract used in Islamic banking because it uses the Arabic terms. When asked about the response to the existence of the contract, they answered 
that they do not object, but they suggest that Islamic bank needs to be socialized so that the public will have better understanding about it.

\section{Conclusion}

Based on the explanation above, it can be concluded that the majority of people who do not understand and know well about the contracts in Islamic banks that use Arabic terms in the products they issue. The use of Arabic terms in Islamic bank products even though on the one hand it functions as the differentiator from the conventional banking products, on the other hand it causes people to have a little difficulty to understand the terms. The public does not object to the use of the Arabic term, but in order to be better understood, it is suggested that the terms are better to be substituted to represent the essence of the product launched or by socializing the terms to the community to increase their understanding about Sharia Finance.

\section{References}

[1] Abdul Sattar Ali Hasan, A. (2011). Al-Irbah al-Tijariyah Min Manzur al-Fiqh al-Islamy. Beirut: Dar al-Nafais.

[2] Al-Jaziriy, A. (1990). Kitab al-Fiqh 'Ala al-Mazhab al-Arba'ah. Beirut: Dar al-Kutub al-'Ilmiyyah.

[3] Darsono, \& Sakti, A. (2017). Dinamika Produk dan Akad Keuangan Syariah di Indonesia. Jakarta: Raja Grafindo Persada.

[4] Fithriani, R. (2018a). Cultural influences on students' perceptions of written feedback in L2 writing. Journal of Foreign Language Teaching \& Learning, 3(1), 1-13.

[5] Fithriani, R. (2018b). Discrimination behind NEST and NNEST Dichotomy in ELT Professionalism. In the 1st Annual International Conference on Language and Literature (pp. 741-755). KnE Social Sciences. https://doi.org/10.18502/kss.v3i4.1982

[6] Fithriani, R. (2019). ZPD and the benefits of written feedback in L2 writing: Focusing on students' perceptions. The Reading Matrix: An International Online Journal, 19(1), 63-73.

[7] Ghoni, A., Suripto, T., \& Salam, A. (2016). Konasi Komunitas Pesantren Yogyakarta dalam Penggunaan Arabic Terms dan Indonesian Terms pada Skim Produk Bank Syariah Al Falah. Journal of Is/amic Economics, 1(2), 149-150.

[8] Hermawan Adinugraha, H. (2017). Simbolisasi Dan Ikonisasi: Metode Alternatif Memahami Arabic Terms Pada Produk Perbankan Syariah. Jurnal Ekonomi Syariah, 
$5(1), 68-69$.

[9] Marliyah. (2016). Strategi Pembiayaan Mudharabah Sektor Usaha Mikro, Kecil, dan Menengah (UMKM): Studi Kasus Perbankan Syariah di Sumatera Utara. UIN SU.

[10] Musse, A. M. (2015). Awareness of Is/amic banking products and services among non-Muslim students in selected northern universities of Malaysia. Munich: GRIN Verlag.

[11] Rukminto Adi, I. (1994). Psikologi, Pekerjaan Sosial, dan Ilmu Kesejahteraan Sosial: Dasar-dasar Pemikiran. Jakarta: Raja Grafindo Persada.

[12] Rusyd, I. (n.d.). Bidayah al-Mujtahid wa Nihayah al-Muqtasid, Juz II. Semarang: Maktabah Usaha Keluarga.

[13] Sabiq, S. (1983). Fiqh as-Sunnah. Beirut: Dar al-Fikr.

[14] Walgito, B. (2003). Pengantar Psikologi Umum. Yogyakarta: Andi.

[15] Walgito, B. (2013). Psikologi Sosial: Suatu Pengantar. Yogyakarta: Andi.

[16] Werdi Apriyanti, H. (2018). Model Inovasi Produk Perbankan Syariah di Indonesia Economica. Jurnal Ekonomi Islam, 9(1), 90. 